\title{
INTERNATIONAL CONTROL OF CIVIL PROCEDURE: WHO BENEFITS?
}

\author{
ROBERT B. VON MEHREN*
}

I

\section{INTRODUCTION}

This article considers the work of the Hague Conference on Private International Law in the field of civil litigation, focusing particularly on the Service Convention and the Evidence Convention. It discusses the most important issues of interpretation and application that have arisen under these two conventions. It notes that the Hague Conference has made a significant international contribution to the process of international civil litigation through these conventions. It concludes that the international community has benefitted from the work of the Conference through cooperation under its auspices, leading toward solutions of procedural problems in international litigation and resulting in the facilitation of international service of process and international discovery.

\section{What is Civil Procedure?}

In the broadest sense, civil procedure constitutes the principles and rules which control the judicial resolution of civil disputes. Civil procedure is found in many places-codes, court rules, court decisions, generally accepted practices-but only to a very limited extent in multilateral international conventions or bilateral international arrangements.

With the development of the centralized state and the emergence of national court systems, the sovereign's writ ran throughout the land. It did not, however, run beyond the territorial boundaries of the kingdom. The territorial focus of sovereignty made it inevitable that civil procedure would develop on a national rather than an international basis.

This development led to diversity, inconsistencies, and, in some instances, incompatibilities among the civil procedures of states having trading and other commercial relations. The areas of service of process and evidence may be taken as examples. In the United States, the Federal Rules of Civil Procedure allow service by mail; this type of service, however, is not recognized in many countries that have important commercial relations with the United States. In

* Retired Partner, Debevoise \& Plimpton, New York. 
the area of evidence, the differences are even more pronounced. Pretrial discovery, which most U.S. litigators accept as one of the inalienable rights of man, is largely unknown outside of U.S. courts. Indeed, the basic roles of the advocate and the judiciary in the gathering and presentation of evidence differ widely among national judicial systems.

Thus, in the two most important procedural areas to which the Hague Conference has addressed itself to date-the commencement of litigation and the gathering and presentation of evidence in court-inconsistencies and incompatibilities have existed between the practice of the United States and countries such as Germany, France, and the United Kingdom.

\section{III}

\section{The Hague Conference and Civil Procedure}

The Hague Conference's most important contributions to cooperation in civil procedure in international litigation are the Convention on the Service Abroad of Judicial and Extrajudicial Documents in Civil or Commercial Matters (the "Service Convention") 1 and the Convention on the Taking of Evidence Abroad in Civil or Commercial Matters (the "Evidence Convention"). ${ }^{2}$ This article presents some reflections on the benefits which the international community derives from these Conventions.

\section{A. The Service Convention}

Litigation traditionally begins with the service of process. As a general proposition, service is important in two respects. First, it may confer jurisdiction in some cases, and, second, it functions to give notice of the nature and venue of the case to the defendant.

Different national systems provide for different modes of service. For example, the United States Federal Rules of Civil Procedure provide that service in a foreign country may be made "by any form of mail, requiring a signed receipt, to be addressed and dispatched by the clerk of the court to the party to be served," 3 and that domestic service may be made "by mailing a copy of the summons and of the complaint . . . to the person to be served, together with two copies of a notice and acknowledgement ... and a return envelope, postage prepaid, addressed to the sender." 4 Service by mail is

1. Convention on the Service Abroad of Judicial and Extrajudicial Documents in Civil or Commercial Matters, opened for signature Nov. 15, 1965, art. 2, 20 U.S.T. 361, 658 U.N.T.S. 163 [hereinafter Hague Service Convention].

2. Convention on the Taking of Evidence Abroad in Civil or Commercial Matters, opened for signature Mar. 18, 1970, art. 2, 23 U.S.T. 2555, 847 U.N.T.S. 231 [hereinafter Hague Evidence Convention].

3. FED. R. CIV. P. 4(i)(1).

4. Id. at $4(\mathrm{c})(2)(\mathrm{C})(\mathrm{ii})$. This type of service is not effective unless an acknowledgement of service is received by the sender within 20 days after the date of mailing. 
generally not recognized by other jurisdictions for the purposes of either domestic or foreign service. ${ }^{5}$

1. The Objective of the Service Convention. The Service Convention entered into force on February 10, 1969. As of the beginning of 1992, twenty-nine countries were parties to the Convention, and two others had signed but not yet ratified the Convention. States party to the Convention presently include, among others, Belgium, Canada, China, France, Germany, Italy, Japan, the Netherlands, Spain, Sweden, the United Kingdom, and the United States. ${ }^{6}$

The preamble to the Service Convention declares the desire of the signatories "to ensure that judicial and extrajudicial documents to be served abroad shall be brought to the notice of the addressee in sufficient time" and "to improve the organisation of mutual judicial assistance for that purpose."7 Certainly, these are laudatory objectives. Moreover, in their implementation, Articles 15 and 16 of the Convention establish protections for the citizens and residents of the signatories who are subject to service. Article 15 codifies the general concept that notice sufficient to afford an opportunity to defend is an essential element of due process of law, a concept which is found in both customary international law and the Constitution of the United States. In essence, it provides that a default judgment shall not be entered against a nonappearing defendant unless (a) service has been properly made pursuant to the internal laws of the state of service or (b) actual delivery to the defendant or his residence of the document in question has been made by a method provided by the Convention in sufficient time to enable the defendant to defend. ${ }^{8}$ Article 16 provides for relief to a nonappearing defendant who can show that, without any fault on his part, he did not have knowledge of a writ of summons in sufficient time to defend or knowledge of a judgment in sufficient time to appeal. ${ }^{9}$

The Service Convention creates a system of service of judicial process-available to litigants in the courts of all of its signatory states-which allows effective service and, at the same time, affords the protection of due process as defined in Article 16. Therefore, the Service Convention provides a codified (and thus reasonably ascertainable), fair, and internationally recognized system for the initiation of litigation. The benefit which this affords the world community will, of course, grow with additional ratifications of the Convention.

5. Germany and Japan are examples of such jurisdictions.

6. TREATIES IN FORCE: A LiST OF TREATIES AND OTHER INTERNATIONAL AGREEMENTS OF THE UNITED STATES IN FORCE ON JANUARY 1, 1992, at 341 [hereinafter TREATIES IN FORCE]. The other states party to the Service Convention are Antigua and Barbuda, Barbados, Botswana, Cyprus, Czechoslovakia (which has since split into the Czech Republic and Slovakia), Denmark, Egypt, Finland, Greece, Israel, Luxembourg, Malawi, Norway, Pakistan, Portugal, Seychelles, and Turkey. Id.

7. Hague Service Convention, supra note 1 , at 362.

8. Id. at 364.

9. Id. 
2. Does the Convention or Local Law Control Where Service is Made on a Domestic Agent? The question has arisen, in the context of service in the United States upon a subsidiary of a foreign corporation in an effort to serve the parent corporation, whether the effectiveness of such service is governed by the Convention or by local law. In Volkswagenwerk Aktiengesellschaft $v$. Schlunk, ${ }^{10}$ the United States Supreme Court decided that such service was domestic service completed within the forum state and governed by local law. ${ }^{11}$ Since the applicable Illinois law" ${ }^{12}$ did not require the transmission of any judicial document for "service abroad," the Convention did not apply. The majority also noted that the Convention was a viable alternative to the use of domestic methods of service in that it provides a "simple and certain means by which to serve process on a foreign national." 13 The choice of such a means would eliminate any uncertainty as to the controlling law, and would result in the protections of Articles 15 and 16 being available to the party being served.

The three concurring justices in Schlunk disagreed with the majority's conclusion that the service made in Illinois was not "service abroad" within the meaning of Article 1, and, therefore, determined that the Convention controlled. ${ }^{14}$ Their disagreement was based on the general purposes of the Convention and its negotiating history. In particular, Justice Brennan noted the discussions concerning the civil law procedure of "notification au parquet," which permits service of process upon a local official, who is then supposed, but not required, to transmit the document abroad through diplomatic or other channels. ${ }^{15}$ This procedure does not assure that the defendant will receive timely actual notice of the pending lawsuit. Consequently, "notification au parquet" is generally viewed as inconsistent with the standards of due process. The concurring justices concluded that the desire of the Tenth Hague Conference to eliminate "notification au parquet" required that the Convention be interpreted to limit the "forum's ability to deem service 'domestic,' thereby avoiding the Convention terms." 16

The difference between the majority and concurring opinions in Schlunk rests in their views of the applicability of Articles 15 and 16. Those Articles provide for relief to a defendant against whom a judgment has been entered who did not have "sufficient time to enable [him] to defend." 17 However, if the service in question was "domestic service" rather than "service abroad," the protection afforded by Articles 15 and 16 would not be available, and the defendant would have to seek relief under the due process concepts of the

10. 486 U.S. 694 (1988)

11. Id. at 707 ("Where service on a domestic agent is valid and complete under both state law and the Due Process Clause, our inquiry ends and the Convention has no further implications.").

12. See ILL. REV. STAT. ch. 110, I 2-209(a)(1) (1985).

13. Volkswagenwerk, 486 U.S. at 706.

14. Id.

15. See, e.g., id. at 709-10.

16. Id. at 714 .

17. Hague Service Convention, supra note 1, at 364. 
applicable domestic laws. This is clearly an unsatisfactory situation, which could be cured by revising the Convention to make Articles 15 and 16 applicable whenever the party effecting service could have used the Convention procedure. Alternatively, the Convention could be interpreted to prohibit the use of "domestic service" unless the service afforded by the domestic procedure is generally equivalent, in terms of the probability of the defendant receiving proper notice, to the forms of service prescribed by the Convention.

3. Does Article 10 of the Convention Allow Service of Process to be Made by Mail? Another subject of litigation in the United States has been the question whether Article 10 of the Convention allows service of process by mail in the absence of an objection by the country where the mail is to be delivered. This problem arises from the language of Article 10(a), which provides that, in the absence of such an objection, the Convention shall not interfere with "the freedom to send judicial documents, by postal channels, directly to persons abroad."18 The ambiguity resides in the use of the verb "to send" rather than "to serve," the argument being that the use of the former implicitly prohibits the "service" of documents by mail. There is a conflict among the federal courts of appeals on this question. The United States Court of Appeals for the Second Circuit held in Ackermann v. Levine ${ }^{19}$ that such service of process is allowed; meanwhile, the United States Court of Appeais for the Eighth Circuit held to the contrary in Bankston v. Toyota Motor Corp. ${ }^{20}$

The existence of a conflict between circuit courts is a significant basis on which the United States Supreme Court exercises its certiorari jurisdiction. Thus, it is not unreasonable to anticipate that this issue will be decided by the Court in the not-too-distant future when an appropriate case presents itself. It is the present position of the Permanent Bureau of the Hague Conference that Article 10(a) does permit service of process by mail:

The view that Article 10(a) does not allow service of process by mail is, so far as we know at the Permanent Bureau, entirely contrary to the historical interpretation of the 1965 Convention as well as the similar language (in French only) in its predecessors, the 1954 Convention on Civil Procedure and the 1905 Convention on Civil Procedure. The idea that the Convention permits service of process by mail, not merely sending of documents, was implicit in the conclusions of the Special Commission which met in November 1977 to consider the operation of this Convention, as well as of the Special Commission of April 1989, which met to consider the operation of both Conventions. Service of process by mail under the Convention has also been upheld by courts in Belgium and we at the Permanent Bureau are not aware

18. Id. at 363 .

19. 788 F.2d 830 (2d Cir. 1986).

20. 889 F.2d 172 (8th Cir. 1989). For a summary of decisions dealing with this question, see

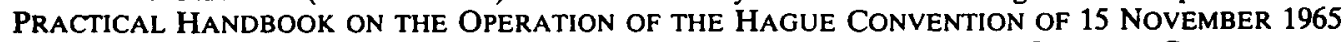
ON SERVICE ABROAD OF JUDICIAL AND EXTRAJUdiCIAL DOCUMENTS IN CIVIL OR COMMERCIAL MATTERS 42-45 (2d ed. 1992). 
of any case, except in the United States, where a court has held that the Convention does not allow service of process by mail abroad. ${ }^{21}$

Although uncertainty as to service by mail may remain, the Convention provides for a procedure which eliminates the question. Instead of serving by mail, the person desiring service may make use of the organ for receiving requests for service, the Central Authority, which each contracting state is required to designate pursuant to Article 2. Following the procedures established by Articles 3 through 7, the Central Authority will either serve the document itself or arrange to have it served by an appropriate agency. Thus, the Convention assures a reliable and fair means of service of process, which is a benefit to parties involved in international litigation within the scope of the Convention.

\section{B. The Evidence Convention}

Evidence is a sine qua non of litigation. In the absence of witnesses and other sources of evidence, the search for the judicial truth, which is the goal of litigation, can never be fulfilled. All judicial systems have procedures for the gathering of evidence and rules governing the presentation of evidence to the court. These systems, however, cannot operate extraterritorially without the cooperation or acquiescence of the sovereign of the territory in which the evidence is sought. When the world was less closely knit, commercially and financially, than it is today, the absence of any system of international cooperation for the gathering of evidence was probably of little practical significance. With the dramatic changes in the structure of international finance and commerce since the end of World War II, the scene changed and a need for cooperation emerged.

The final text of the Evidence Convention was prepared at the Eleventh Session of the Hague Conference on Private International Law and was signed by all of the delegations present on October 26, 1968. The Convention entered into force on October 7, 1972. Presently, twenty-one states are parties to the Convention, including Argentina, Mexico, France, Germany, Italy, the Netherlands, Singapore, Sweden, the United Kingdom, and the United States. ${ }^{22}$

Whatever service or disservice the Evidence Convention provides for the international community, one thing is clear: the Convention addresses a problem of international civil litigation which requires international cooperation. If all of the relevant evidence could always be provided by the parties to the litigation, adequate solutions might well be found within national systems of discovery and trial. A trial court usually has available sanctions which will, if fully applied, force parties before it to disclose evidence to which they have access or which is within their control. For example, failure to produce evidence

21. Letter from Adair Dyer, First Secretary, Hague Conference, to the author (June 19, 1992) (on file with author).

22. TREATIES IN FORCE, supra note 6, at 341-42. The other states party to the Evidence Convention are Barbados, Cyprus, Czechoslovakia (which has since split into the Czech Republic and Slovakia), Denmark, Finland, Israel, Luxembourg, Monaco, Norway, Portugal, and Spain. Id. 
required by a U.S. federal court can result in sanctions as serious as entry of judgment against the offending party. ${ }^{23}$ Whether that power will be exercised depends upon the specific facts of the case. Where a blocking statute or other foreign law imposing penalties for the disclosure of the evidence sought exists, the trial court may decide that the party against whom the order is directed should not be penalized for noncompliance. The most satisfactory solution to conflicts of this type between the forum state and the blocking state requires some mechanism for the impartial weighing of the conflicting interest. No such mechanism exists today.

Another difficulty arises where evidence is in the control of a nonparty outside the jurisdiction of the trial court. In the international environment, if the nonparty controlling the evidence refuses to supply it, then such evidence cannot be obtained without some type of international cooperation. The Evidence Convention provides an international approach to securing nonparty evidence where it is necessary to the proper resolution of civil litigation. ${ }^{24}$

1. The Objective of the Evidence Convention. The preamble to the Evidence Convention states that the signatory states desire "to facilitate the transmission and execution of Letters of Request and to further the accommodation of the different methods which they use for this purpose," and also "to improve mutual judicial co-operation in civil or commercial matters." 25 "Chapter I of the Convention then provides for a regime governing "Letters of Request" to obtain evidence or to perform some other judicial act. ${ }^{26}$ Chapter II provides for the "taking of evidence by diplomatic officers, consular agents and commissioners." ${ }^{27}$ These procedures are designed to balance the interests of the requesting state and the addressed state. The Convention enumerates specific rights and protections for witnesses. Whether the evidence is to be taken under Chapter I (an involuntary procedure) or Chapter II (a voluntary procedure), Article 11 controls. It gives the witness the same privileges or duties to refuse to give evidence that he or she may have under the laws of the addressed state or the laws of the state originating the request. For example, a U.S. citizen testifying under a Letter of Request from Germany retains his or her constitutional privilege not to incriminate himself or herself, and acquires any additional applicable German privilege not found in U.S. law. Thus, the witness is afforded the total protection of the two relevant legal systems.

23. If a party fails to provide or permit discovery, the trial court may make "[a]n order striking out pleadings or parts thereof, or staying further proceedings until the order is obeyed, or dismissing the action or proceeding or any part thereof, or rendering a judgment by default against the disobedient party ...." FED. R. CIV. P. 37(b)(2)(C).

24. See, e.g., In re Anschuetz \& Co., 754 F.2d 602, 615 (5th Cir. 1985) (holding that the Convention "is to be employed with the involuntary deposition of a party conducted in a foreign country, and with the production of documents or other evidence gathered from persons or entities in the foreign country who are not subject to the court's in personam jurisdiction").

25. Hague Evidence Convention, supra note 2, at 2557.

26. Id. at 2557-64.

27. Id. at 2554-65. 
2. Does the Evidence Convention Preempt the Domestic Rule of Civil Procedure? Between 1985 and 1987, this question was the subject of significant litigation in the United States. Many European jurisdictions had taken the position that the Convention preempted the domestic rule; meanwhile, many U.S. jurisdictions had taken the opposite position. For the United States, this question was settled by the Supreme Court's decision in Sociéte Nationale Industrielle Aérospatiale v. United States District Court for the Southern District of Iowa. ${ }^{28}$ There, the Court held unanimously that the Convention does not provide the exclusive procedure for obtaining documents and information located in a foreign signatory's territory. The Court also held, by a five-four majority, that the trial court should make an analysis, similar to that often undertaken by U.S. courts in deciding choice of law questions, which considers and endeavors to balance the competing interests to determine which procedure should be used. The four justices dissenting from the second holding of the Court reasoned that, as a general rule, there should be a presumption "that, in most cases, courts should resort first to the Convention procedures." 29

In reaching this conclusion, the dissenting justices did not discuss the fact that the Evidence Convention imposes no obligation upon the state addressed to accommodate the interests of the forum state by providing evidence which the trial court may view as essential to the proper resolution of the case before it. $^{30}$ For example, blocking statutes or criminal statutes, either preventing or imposing substantial penalties for disclosure, may very well make first recourse to the Convention procedure useless. It is nonsensical to force the domestic party to use a procedure which does not afford a reasonable opportunity of securing the evidence sought. Perhaps, at some point the Hague Conference should consider revising the Convention so that the interest of the trial court in securing relevant evidence can be properly balanced with the addressed state's interest in the nondisclosure of evidence.

3. Is Such a Revision of the Convention Feasible? It may not be realistic to seek such a revision before achievement of a sympathetic understanding of different approaches to discovery and trial, such as those that exist between common law and civil law jurisdictions. As a practical matter, in many situations, both the requesting state and the state addressed may have to alter their domestic practices to strike an appropriate balance between the interests of the state of trial and the state where the evidence was sought. Such an accommodation would be more easily achieved if limitations on U.S. discovery practice were established through changes in the Federal Rules of Civil Procedure so that the scope of federal discovery would be more acceptable to other states. The American Bar and judiciary is now directing substantial attention to the desirability of such a limitation.

28. 482 U.S. 522 (1987).

29. Id. at $547,548-49$ (Blackmun, J., concurring in part and dissenting in part).

30. See generally id. at 547-68. 
In practice, since the Aérospatiale decision, most U.S. courts have applied the domestic system where evidence is sought from a party who is subject to the personal jurisdiction of the court. This result is perhaps inevitable while the holding in Aérospatiale remains the controlling law. Unless another approach is mandated, both U.S. judges and U.S. lawyers will opt for the familiar procedure rather than the relatively unfamiliar Convention procedure. ${ }^{31}$ The whole situation could be altered by a change in Rule 26 of the Federal Rules of Civil Procedure. Such a change was proposed in the June 1990 recommendations of the Advisory Committee on Civil Rules of the Standing Committee on Rules of Practice and Procedure of the Judicial Conference of the United States. The proposal, which was explicitly based on the dissenting view in Aérospatiale, was to add to Rule 26(a) the following language:

\begin{abstract}
Discovery at a place within a country having a treaty with the United States applicable to such discovery shall be conducted by methods authorized by the treaty unless the court determines that those methods are inadequate or inequitable and authorizes other discovery methods prohibited by the treaty. ${ }^{32}$
\end{abstract}

This recommendation was included in the draft of the Report of the Judicial Conference Committee on Rules of Practice and Procedure of September 1992. The Judicial Conference, however, deleted this proposed amendment in response "to criticisms from the Departments of State and Justice and from certain foreign governments." 33

The Report was transmitted to the Chief Justice of the United States on November 27, 1992, and the proposed amendments, including significant amendments to Rule 26 mandating disclosure and providing for other significant changes in that rule, became effective December $1,1993 .^{34}$

\title{
31. See FED. R. CIV. P. 26.
}

32. See report by the Advisory Committee on Civil Rules of the Standing Committee on Rules Practice and Procedure of the Judicial Conference of the United States, dated June 19, 1990. A somewhat more elaborate change was proposed in a Preliminary Draft of Proposed Amendments to the Federal Rules of Appellate Procedure and the Federal Rules of Civil Procedure, dated September 1989. See 127 F.R.D. 237, 317-21 (1990). In an article published shortly before the June 19, 1990, recommendation, the Honorable Joseph F. Weis, Jr., of the United States Court of Appeals for the Third Circuit and Chair of the Standing Committee on Rules of Practice and Procedure of the Judicial Conference had supported the dissenting position in Aérospatiale:

The arguments mustered against giving priority to Convention procedures are not persuasive when balanced with the overriding interests, national and international, in more effective implementation of the Evidence Convention. It should be remembered, after all, that the treaty negotiated by the United States and the other signatories is for the benefit of private litigants as a whole-some inconvenience or expense to an individual litigant should not suffice to jeopardize an arrangement which benefits many. Moreover, through ratification, the United States has agreed to honor the commitments which the treaty contains. The judiciary should not lightly permit a private litigant to undermine express national policy.

Joseph F. Weis, Jr., The Federal Rules of the Hague Conventions: Concerns of Conformity and Comity, 50 U. PITT. L. REV. 903, 931 (1989).

33. Excerpt from the Report of the Judicial Conference Committee on Rules of Practice and Procedure, 146 F.R.D. 515 (1993).

34. Federal Rules of Civil Procedure: Amendments to Federal Rules of Civil Procedure, 146 F.R.D. 401, 401-03, 514 (1993). 
No proposal to amend Rule 26 to give priority to the Evidence Convention procedure has been presented to the Supreme Court. Whether any such amendment would ever be proposed by the Judicial Conference and accepted by the Court will probably be determined within the context of the recent amendments to Rule 26, providing for required disclosure and comporting with the general context of the continuing debate as to whether and how to reform what some view as the oppressive system of federal discovery.

IV

\section{OVERVIEW AND CONCLUSION}

Certain benefits flowing from the Service and Evidence Conventions specifically relate to international litigation. Before discussing these, a broader question should be addressed: are there other, more general benefits coming from the Hague Conference on Private International Law?

One of the difficulties of international litigation has been, and remains, the fundamental differences among various national systems with regard to the role of the advocate and the judiciary in securing evidence. A paper which I delivered in 1983 discussed the perspective of the U.S. private practitioner on discovery of documents and evidence in a foreign country, and noted that there were profound differences between the U.S. approach to discovery and those of the United Kingdom and Italy - the two jurisdictions selected for comparison. ${ }^{35}$ These differences reside not only in the scope of discovery but also in the role of the advocate and the judiciary in collecting evidence. ${ }^{36}$

The work of the Hague Conference has been very useful in developing an understanding and, to some extent, an accommodation of these differences. The Evidence Convention rests on the fundamental concept of providing a method for gathering evidence "'tolerable' to the authorities of the state where it is

35. Robert B. von Mehren, Perspective of the US Private Practitioner, in EXTRATERRITORIAL APPLICATION OF LAWS AND ReSPONSES Thereto 194.(Cecil J. Olmstead ed., 1984).

36. These differences were summarized as follows:

The American, English and Italian definitions of these roles constitute something of a spectrum. At one extreme is the US practice where the judicial role in the discovery process is supervisory and the lawyers are active and wide-ranging. In the middle is that of the United Kingdom, where the lawyers play active but subdued roles. At the other extreme is Italy where the role of evidence-gathering is primarily that of the judiciary.

Id. at $195-96$.

In the Italian system, any step undertaken by a party in the discovery process must be authorized by the court, which has wide discretion to deny discovery if it is not deemed necessary. Furthermore, the judge will always be present at the taking of evidence and, as stated above, whenever a party or witness is examined, the judge will personally conduct the questioning. The inquisitorial nature of the Italian system and the central role played by the judiciary in collecting evidence are emphasized by the court's power on its own initiative:

(1) personally to inspect things or persons which are indispensable to ascertain the truthfulness of facts, and

(2) to request parties to appear before it and question them about the action. 
taken and at the same time 'utilizable' in the forum where the action will be tried." 37

The foundation of the Convention is the necessity for international cooperation and accommodation. That this can in fact be achieved in important areas is illustrated by the accommodation between U.S. discovery conducted by the advocate and French discovery conducted by the judge. After France joined the Evidence Convention, a new French Code of Civil Procedure, adopted in 1975, allowed cross-examination of witnesses and a verbatim transcript when requested under a foreign Letter of Request. ${ }^{38}$ These procedures are not known in French domestic practice and were incorporated into French civil procedure specifically to meet the needs of U.S. practice and, particularly, the U.S. deposition. ${ }^{39}$

Turning now to final conclusions, it seems that the following specific and significant benefits have been achieved in international litigation through the Service and Evidence Conventions:

1. A procedure, certain and ascertainable, for instituting litigation has been established by the Service Convention.

2. An internationally defined and enforceable standard of due process with respect to service has been set forth in the Service Convention.

3. The problem of obtaining evidence from reluctant third-party witnesses has been addressed in the Evidence Convention, and a procedure, which could not be created unilaterally, for obtaining such evidence has been established.

4. Witnesses testifying or producing documents pursuant to the Evidence Convention have been assured by international agreement the protections and privileges afforded witnesses in both the forum state and the state in which the testimony or documents are being sought.

Finally, the very existence of an organization such as the Hague Convention on Private International Law must itself be viewed as a benefit to the international community. The Convention has provided a forum for the discussion of particular problems and has allowed international initiatives in areas which otherwise might not have been addressed. Other articles in this symposium address the Child Abduction Convention ${ }^{40}$ and the cases for a Foreign Sovereign Immunity Convention and a Foreign Judgment Convention. ${ }^{41}$ Who could provide a forum for such discussions superior to that of the

37. See Report of the United States Delegation to Eleventh Session of Hague Conference on Private International Law, 8 I.L.M. 785, 806 (1969).

38. FR. C. PR. CIV., arts. 733-38.

39. See Adair Dyer, Note on the Aérospatiale Case, 77 RevUe CRITIQUE DE DROIT INTERNATIONAL PRIVE. 575, 579-80 (1988).

40. Linda Silberman, Hague International Child Abduction Convention: A Progress Report, 57 LAw \& CONTEMP. PROBS. 209 (Summer 1994).

41. Joan E. Donoghue, The Public Face of Private International Law: Prospects for a Convention on Foreign State Immunity, 57 LAw \& CoNTEMP. ProBs. 305 (Summer 1994); Andreas F. Lowenfeld, Thoughts About a Multinational Judgments Convention: A Reaction to the von Mehren Report, 57 LAW \& Contemp. Probs. 289 (Summer 1994); Horace B. Robertson, Jr., Comments on Professor Joan E. Donoghue's Article, The Public Face of Private International Law: Prospects for a Convention on 
Hague Conference?

Foreign State Immunity, 57 Law \& Contemp. Probs. 323 (Summer 1994); Arthur T. von Mehren, Recognition and Enforcement of Foreign Judgments: A New Approach for the Hague Conference?; 57 LAW \& CONTEMP. Probs. 271 (Summer 1994). 